Notre Dame Law School

NDLScholarship

1981

\title{
Professional Independence and the Associate in a Law Firm: A French Case Study
}

Tang Thi Thanh Trai Le

trai.t.le.2@nd.edu

Follow this and additional works at: https://scholarship.law.nd.edu/law_faculty_scholarship

Part of the Comparative and Foreign Law Commons, and the Legal Profession Commons

\section{Recommended Citation}

Tang Thi Thanh Trai Le, Professional Independence and the Associate in a Law Firm: A French Case Study, 29 Am. J. Comp. L. 647 (1981).

Available at: https://scholarship.law.nd.edu/law_faculty_scholarship/17

This Response or Comment is brought to you for free and open access by the Publications at NDLScholarship. It has been accepted for inclusion in Journal Articles by an authorized administrator of NDLScholarship. For more information, please contact lawdr@nd.edu. 


\title{
Comments
}

\section{PROFESSIONAL INDEPENDENCE AND THE ASSOCIATE IN A LAW FIRM: A FRENCH CASE STUDY}

\author{
Tang Thi Thanh Trai Le*
}

In June 1977, as a result of a case brought before the Tribunal de la Seine,1 a "mini-revolution"2 erupted in French legal circles. A young woman associate of a law firm was discharged at mid-month and paid half (F. 1250) her monthly salary. Mme X considered her dismissal improper and filed a complaint with the Batonnier (President) of the Paris Bar. ${ }^{3}$ After a hearing, the Conseil de l'Ordre (Executive Committee of the Bar) advised the firm to pay Mme X an additional F. 1250 in settlement. Not satisfied, Mme $X$ took her case to the Tribunal de la Seine requesting compensatory damages of F. 2750 (F. 2500 for one month's notice and F. 250 for vacation time not taken) and punitive damages of F. 10,000.

Why did Mme X's case stir such great interest in the French legal community? For the first time in French history, an avocat (practicing attorney) asked a court to apply labor law ${ }^{4}$ in the resolution of an employment dispute with another avocat. By doing so, Mme X represented herself as being an employee despite her status as an avocat. Thus, Mme $\mathrm{X}$ rekindled a perennial debate of the

* Member, Board of Editors. This Comment is the partial result of a study on Comparative Legal Ethics funded by the Dana Foundation.

1. Mme X. . . . c. Association d'Avocats Y. . . . et autres, Tribunal d'instance de Paris, 8 April 1977, J.C.P., II, 19676; Recueil Dalloz Sirey at 589. The parties are designated $X$ or $Y$ when readily identifiable in the community. See text accompanying $n$. 85 infra for a discussion of the decision of the Tribunal.

2. The term was used by Le Monde, 26 April 1977 at 16; also Le Monde, 3 September 1977 at 1 . Civil proceedings are rarely covered in the French press. One commentator observed that Mme X's case so aroused the interest of the legal community as to warrant the attention of the daily press. Denis, Note, Tribunal d'instance de Paris, 8 April 1977, Dalloz 1977 at 591.

3. Under art. 33 of the Internal Rules of the Paris Bar, all ćlaims brought by an avocat against another avocat must first be heard by the Batonnier. The Batonnier can recommend a settlement or refer the matter to the Conseil de l'Ordre. (The term Batonnier was first used in 1602 . It comes from the baton carried by the head of the Bar, symbolizing his authority.)

4. French labor law is an autonomous body of law originally providing special protection for industrial workers. It was later extended to cover white-collar employees. The autonomy of French labor law has been strengthened by the establishment of separate tribunals which follow special procedures. 
French legal profession: Can an avocat be characterized as an employee?

At the core of this debate is the principle that the profession of avocat is "liberal"5 and "independent." This concept has been recognized over the centuries 6 and was codified into law in $1971 .^{7}$ The Internal Rules of the Paris Bar make the principle of independence a matter of professional ethics. ${ }^{8}$ Thus, the characterization of an avocat, even an avocat who is also a collaborateur (associate), as merely an employee threatens the mandated independence of the profession. Any infringement upon the independence of the avocat would be a violation of ethical rules. ${ }^{9}$

Before discussing the threat to professional independence by the characterization of a collaborateur as an employee however, a few remarks on the organization of the legal profession in France are in order.

\section{The French Legal Profession}

The various functions normally performed individually by American attorneys are performed by a variety of French legal professionals. Prior to the 1971 reorganization of the legal professions, the practitioners included the avocat, the avoué, the agrée, the notaire and the conseil juridique. ${ }^{10}$

During the Gaullist period, an attempt was made to integrate the French legal professions into a single "great profession."11 The treaty establishing the Common Market contained provisions dealing with free movement of services and freedom of establishment among Common Market countries. ${ }^{12}$ These provisions provided the

5. For an explanation of the term "liberal," see text accompanying n. 46 infra.

6. The first oath of the avocat asserting the principle of independence is contained in an ordinance issued by Philippe le Hardi in 1274. The present oath is essentially identical: "I swear as an avocat, to exercise the defense and counsel with dignity, conscience, independence and compassion, with respect to tribunals, public authorities, and the rules of my Order, and not to say or publish anything which is contrary to the law, regulations, good morals, security of the state and public peace." Decree No. 72-468, 9 June 1972 (Journal Officiel, 11 June 1972 and J.O. 6 July 1972) art. 23.

7. Law No. 71-1130, 31 December 1971 (J.O. 5 January 1972) art. 7.

8. Reglement Intérieur du Barreau de Paris, Preface and art. 18.

9. Id., Preface.

10. The avocat is a member of the self-governing bar and is responsible to the Conseil de l'Ordre. The avocat is required to remain independent of his client and, somewhat like the English barrister, specializes in oral advocacy. The avoue is an officier ministeriel (ministerial official) appointed by the state. The avoue is considered the client's agent and is restricted to written advocacy. The agré performs functions similar to those of the avocat and avoue before the commercial courts. The notaire is responsible for drafting instruments concerning landed estates, inheritances, corporations and the status of persons. Conseils juridiques, free of regulation until the reform of 1971 , give advice in the commercial and financial areas.

11. See Herzog \& Herzog, "The Reform of the Legal Professions and of Legal Aid in France," 22 Int. \& Comp. L.Q. 462 (1973).

12. Treaty Establishing the European Economic Community (Common Market), 298 U.N.T.S. 140, Arts. 52-66. 
incentive for bringing the French legal profession into line with the legal professions of the other Common Market countries. The Government and the Association Nationale des Avocats favored this reform. ${ }^{13}$ Other groups of legal professionals however thought the proposed reform too brutal ${ }^{14}$ and an unnecessary "upheaval of institutions." 15

Ultimately a compromise was effected. Law No. 71-1130 promulgated on 31 December 1971, modestly entitled "Reform of Some Legal Professions," merged the professions of avocat, avoué ${ }^{16}$ and agrée. Further, the law simply regulates the profession of conseil juridique to facilitate its eventual merger with that of avocat in the future. ${ }^{17}$

Thus, despite the reform, the French avocat has a more restricted practice than his American counterpart. Similarly, the status of the French collaborateur differs from that of the American associate.

The term "collaborateur" designates an avocat working for another avocat. Since the particular process by which a law student makes the transition to avocat is highly formalized when contrasted with the process by which an American law student moves from law school into practice, some explanation is required.

To become registered with a local bar as an avocat, a candidate must first be a French citizen and have the degree of a Licence on droit (after four years of study) or a Doctorat en droit (after qualifying for a Licence, taking advanced courses, and preparing a dissertation in a specific field). Second, the candidate must pass a professional examination, the "Certification of Aptitude for the Legal Profession" (C.A.P.A.). Finally, the candidate must take an oath and register with the bar. The candidate is then an "avocat stagiaire" (lawyer in training) and his name is placed on the "liste du stage" (list of avocats in training). ${ }^{18}$

The period of training, ${ }^{19}$ normally three years, is conducted in conjunction with the Centers of Professional Training, partially funded by the State and located at the seat of each regional cour d'appel (intermediate appellate court). ${ }^{20}$ Instruction is given by law professors, judges, prosecutors and members of the bar. The avocat stagiaire attends programs organized by the Centers and acquires

13. Herzog, supra n. 11 at 462 .

14. See report of Zimmerman, J.O., Assemblee Nationale, 13 October 1971 at 458.

15. Lobin, "Réflexions sur certains aspects de la réforme des professions judiciaires," Dalloz, 1972, Chronique, at 36.

16. The avoués practicing before the cours d'appel (intermediate appellate courts) were unaffected by the reform.

17. The legal training, good morals, professional practice and registration required of avocats are now also imposed upon the conseil juridique. See Law No. 711130 , supra n. 7, art. 54-56.

18. Id., art. 11; Decree No. 72-468, supra n. 6, art. 23-24.

19. Candidates with legal experience such as magistrates, law professors and former avoues are exempt from this period of training. See id., art. 46.

20. Law No. 71-1130, supra n. 7, art. 12-14; Decree No. 72-468, supra n. 6, art. 26-42. 
practical skills through working with various legal practitioners such as avoues, conseils juridiques, experts comptables (certified public accountants) or avocats. ${ }^{21}$ Positions in the office of an avocat are the most sought after since exposure to a law firm is considered the best means of acquiring practical knowledge of the legal profession. During this training period, the young avocat must use the title of "avocat stagiaire" and not simply that of avocat.22 The avocat stagiaire may cultivate his own clientele and represent them in court. ${ }^{23}$ The status of collaborateur-avocat stagiaire is a temporary one, ending with completion of the training period. Upon the Conseil de l'Ordre's finding that he has performed his duty satisfactorily, the avocat stagiaire is accepted as an avocat titulaire (fullfledged lawyer) entitled to all the rights of a regular member of the bar, including the right to elect the Conseil de l'Ordre. ${ }^{24}$

An avocat titulaire is faced with a number of alternatives. He may (1) establish a solo practice; (2) practice en groupe in either an association (loose partnership) or in a societe civile professionnelle (professional corporation); or (3) work with one or more other avocats as a collaborateur. ${ }^{25}$ The first alternative requires no explanation. The avocat choosing to practice en groupe shares mutual responsibility with his colleagues. Each member is equal in stature. ${ }^{26}$ However, the avocat who chooses the third alternative of working as a collaborateur does not share in the liability and responsibility of the avocat with whom he is associated. Other aspects of his status are somewhat unclear. For example, the same definition is given for the temporary collaboration of the avocat stagiaire and the more permanent collaboration of the avocat titulaire. The Internal Rules of the Paris Bar provide that "collaboration" for both requires the lawyer "to undertake to devote, without any bond of subordination and to the exclusion of any occasional or temporary help, all or part of his activities to the practice of another

21. An avocat stagiaire, although in training, can be a partner (associe) of a firm. This can occur, for example, if the avocat stagiaire can bring a substantial clientele to the firm.

22. Decree No. 72-468, supra n. 6, art. 82. Reglement Interieur du Barreau de Paris, art. 1(5). Understandably, young avocats are not happy with this restriction and have worked for its suppression. See Lemaire, Les Regles de la Profession d'Avocat et les Usages du Barreau de Paris 177 (1975).

23. Decree No. 72-488, supra n. 6, art. 38 .

24. Id., arts. $1,3,5$.

25. Law No. $71-1130$, supra n. 7 , art. 8 .

26. Until 1954, legal practice en groupe was not authorized in France. It was believed that any association among avocats would infringe upon both the independence of the avocat and the client's need for confidentiality. A decree of 1954 (No. 54406, 10 April 1954) first authorized grouping among avocats, but only under a form (association) not cognizable as a legal entity. The association cannot be registered with the bar as such. It simply creates obligations between avocats in association, such as the duty not to represent a client whose interest contradicts that of another member's client and not to accept a case objectionable to another member of the association. The more cohesive form of group practice, the Societe civile professionnele, applicable to all "liberal" professions, is comparable to the professional corporation in America. 
lawyer."27 The ambiguity of the collaborateur's status is compounded by the ambiguity of the law governing collaboration between lawyers.

\section{The Ambiguous Contract of Collaboration}

Until $1977,{ }^{28}$ no satisfactory characterization had been given to the legal relationship between an avocat or firm and the collaborateur. The principal question was whether the employer-employee relationship could exist between lawyers. Law No. 71-1130 of 31 December 1971,29 creating and organizing the new profession of avocat, purposely left the question unanswered. The law stated only that the legal profession is a "liberal" and "independent" one and that all activities which impair the independence of the lawyer or the "liberal" character of the profession are "incompatible with the practice of this profession."30 The law does not address the question whether wage-earning by a collaborateur is incompatible with the legal profession. The law simply requires that a written contract be executed "to assure the collaborateurs an equitable remuneration and guarantee their independence."31 Significantly, the contract is not characterized in any way. The law is silent in this regard largely because of the considerable debate that took place in the Assemblee Nationale and the Senat during consideration of the matter. Originally, the government projet de loi (bill) provided that "the lawyer may practice his profession as a sole practitioner, in a partnership, as a member of a professional corporation, or an associate, employee or not, of another lawyer or law firm"32 [emphasis added]. The Commission des Lois (Law Commission) of the Assemblee Nationale deleted the words "employee or not." During discussion of the bill however, the government attempted to reinsert the words by amendment, arguing that:

[T] here is nothing incompatible between working for wages and the practice of a "liberal" profession. This can be seen in other professions. Wage-earning honestly and openly accepted is without doubt preferable to the more or less clandestine kickback of honoraria. This is even more so when the recipients are deprived of the social advantages which accompany wage-earning. ${ }^{33}$

Those opposing the amendment considered this argument specious. One deputy, to the hearty applause of his colleagues, declared:

[T] he independence or dependence of the lawyer is at

27. Reglement Intérieur du Barreau de Paris, Art. 65.

28. The new characterization is given by Law No. 77-685, 30 June 1977 (J.O. 1 July 1977). See text accompanying $n .100$ infra.

29. See n. 11-17 supra.

30. Law No. $71-1130$, supra n. 7 , art. 7.

31. Id., Art. 8.

32. See Blanc, La Nouvelle Profession d'Avocat 58 (1972). Giverdon, "Réflexions sur un avant projet," Dalloz, doctrine at 136.

33. J.O., Assemblee Nationale, 8 December 1971 at 6531. 
stake. ... Take a look at any treatise on labor law and you will discover that the bond of the employee, arising as it does from a contract for the hiring of services, necessarily entails for the employee an obligation to obey the will of his employer, his patron ... Contrary to what some people may think, the lawyer has for his god only the law and for his master only his conscience! The youngest avocat stagiaire and the oldest batonnier are equal under the Robe, and it would be unacceptable that one would call the other his patron..$^{34}$

In the Senat, the government again tried to introduce the concept of salariat (employment) into the projet de loi. The Minister of Justice emphasized the social and economic benefits such a classiffcation would bestow upon the young lawyer. In urging the legislators to do away with the fiction of collaboration whereby a collaborateur only pretends not to take wages, the Minister of Justice concluded the "legislator[s] could do better . . . to look to what really happens." 35 Nevertheless, a majority of the Senat remained unconvinced. As one Senator noted:

The matter of accepting wages is certainly not, in itself, something which degrades the dignity of the one who receives them. But when one accepts a salary one is incontestably placed under the authority of the patron. It is thus not possible for a lawyer, if he is an employee, to remain entirely independent and to decline to argue a case as required by his patron. ${ }^{36}$

Ultimately, the words "employee or not" were deleted. Instead, a new paragraph requiring a written contract of collaboration was added to assure the benefits of fair remuneration as well as to safeguard the avocat's independence. ${ }^{37}$ The Minister of Justice noted that the Government yielded to this compromise because the Ministries of Justice, Economy and Finance had "practically reached [an] accord to define [the] status of the collaborateur [as one] which will give him the same benefits as those given by salariat."38 The Minister thereby implied the creation of a new type of contract, distinct from the contract of employment and applicable only to collaboration between lawyers.

Nevertheless, the decree of 9 June 1972 implementing the law of 31 December 1971 did not clarify the nature of the contract of collab. oration. The new decree only accentuated the ambiguity of the nature of the contract. The decree prescribed the format of the contract of collaboration, requiring that it be written, ${ }^{39}$ but left the

\footnotetext{
34. Id.

35. J.O. Senat, 17 November 1971 at 2021.

36. Id.

37. Law No. 71-1130, supra n. 7, art. 8.

38. J.O. Senat, December 1971 at 3108.

39. Decree No. 72-468, supra n. 6, art. 74.
} 
terms to be determined by the parties within the framework of the bar's internal regulations. ${ }^{40}$

The ambiguity is further accentuated by seemingly contradictory provisions. For example, although under the law a collaborateur is the master of his own argument, he must inform "the lawyer to whom he is bound" of the manner in which he plans to handle each case.41 A collaborateur can ask to be relieved of an assignment which he considers contrary to his conscience or beliefs, ${ }^{42}$ but the lawyer for whom the collaborateur works remains responsible for the collaborateur's professional activities. ${ }^{43}$ These seemingly contradictory provisions justify a commentator's conclusion that "the authors of the reform deliberately abstained from any attempt to characterize the contract of collaboration."44

\section{Traditional v. Functional Approach to Colllaboration}

In order to understand why salaried employment of collaborateurs has met with such staunch opposition by segments of the French legal community, despite convincing pragmatic arguments to the contrary, one must understand the traditional approach to the profession of avocat. In contrast to the functional approach, the traditional approach refuses to let pragmatic considerations interfere with the traditional model of the avocat as a free, independent professional.

\section{The Traditional Approach}

The characterization of the profession of avocat as "liberal" and "independent" is at the heart of the matter. Unfortunately, the law uses the terms "liberal" and "independent" without defining them. ${ }^{45}$ Professor Jean Savatier, in his definitive work on "liberal professions," says that any discussion of the subject must focus on the relation between the professional and his client. To Savatier, this relationship involves three aspects: (1) the nature of the professional's activity; (2) the type of interests entrusted to him and (3) the social mission he assumes. ${ }^{46}$

First Savatier distills the qualities of the professional's activity: it is intellectual, independent and disinterested. However each of these characteristics standing alone is misleading. For example, "intellectual" is not totally appropriate since non-"liberal" professionals such as magistrates and bankers engage in highly intellectual

40. Id., art. 75. The internal rules of the Paris Bar, elaborating art. 75, require that the contract of collaboration contain an express provision excluding any bond of subordination. Reglement Intérieur du Barreau de Paris, art. 65.

41. Decree No. $72-468$, supra n. 6, art. 76.

42. Id.

43. Id., art. 77.

44. Denis, Note, supra n. 2.

45. See n. 30 supra.

46. Savatier, Etude Juridique de la Profession Liberale 35 (1947). 
activities. Also, although "independence" is an important attribute of a "liberal" profession, it is not absolute. For example, doctors employed by clinics or hospitals practice a "liberal" profession even though they are subordinated to their employers. The characterization of a "liberal" profession as "disinterested" explains certain rules applicable to the legal profession such as the "honorarium" concept of legal fees and the traditional ethical rules forbidding lawyers to press their claims against clients for unpaid fees. Savatier asserts however that a profession which allows one to earn a living cannot truly be considered "disinterested." According to Savatier "disinterested" more accurately suggests that a professional must consider the client's interest before his own. Thus, a merchant could refuse credit to an insolvent customer but a doctor could not ethically refuse to treat an insolvent patient.

Second, to Savatier, the nature of the client's interest is the most characteristic feature of the "liberal" profession. Savatier considers the client's interests "sacred" because they are so closely related to the client as a human being. They affect the stability, honor and life of the client. The client looks to the lawyer for what Savatier calls "secours humain" (human help). More than pecuniary and material interest, the client delivers to his lawyer a "part of himself."47

Third, to Savatier, the professional fulfills a social mission by protecting his clients. However, the professional also owes a duty to society at large. Professionalism consists in striking a balance between these two social missions. For this the professional needs independence. He needs independence in order to protect his client's interests; he also needs independence to organize. It is through the ethical rules formulated and imposed by professional organizations that the professional will temper the ardor he feels for his client's interest with a thorough regard for the interests of society at large. ${ }^{48}$

Another proponent of the traditional approach to the "liberal" profession, Batonnier Damien, defines the profession as one which recognizes

material and intellectual independence, a liking for a job well done, a certain disinterest which does not exclude greed or thrift, a certain benevolent fraternalism toward the underdog, public favor considering it one of the ornaments of society, high sense of duty, absolute legal non-accountability, and finally autonomy thanks to its powerful connections, for it is in the last trait that resides the secret of this social category: it belongs to the class who holds power. ${ }^{49}$

Thus, under the traditional approach, avocats perceive themselves as the protectors of the ideals of independence.

47. Id. at 40 .

48. Id. at $34-46$.

49. Communication of Batonnier Damien to the Institut de France, Gazette du Palais 1977, doctrine, at 69. 
Although the principle of independence had always been understood by lawyers, it had never been expressed in any legislative document or regulation prior to its codification into law in 1971. The silence of the law on the matter of independence is best explained by the belief that "[i]t is not necessary to express something which is obvious." 50

The breadth of professional independence can be best delineated by reviewing the ethical rules governing avocat conduct set forth in the various texts regulating the legal profession. The avocat must be independent vis-d-vis his client. This means, among other things, that honorariums (fees) must not be tied to the client's pecuniary interest in litigation. All contingent fees are prohibited.51 This prohibition is imperative, any agreement to the contrary will be considered null and void, ${ }^{52}$ and the avocat drawing this form of remuneration will incur severe disciplinary sanctions. ${ }^{53}$ Independence also dictates that the avocat be free to accept or refuse representation of the client, free to conduct his argumentation and free to defend the client's interest according to his and not the client's judgment. 54

It is in the concept of "incompatibilities" that the principle of independence is made explicit by the law. Incompatibilities are situations which subject the avocat to a "bond of servitude," but also those situations "which, although they do not degrade the character of an individual or give occasion to any depreciation of his abilities, nevertheless restrict his will, give others the right to prevail upon his time, and subject him to personal obligations or duties of a subordinate to which he is required to accommodate himself under pain of reprimand or the loss of a more or less lucrative position."55 Incompatibilities also involve situations in which the avocat's activities are simply motivated by pecuniary gain. Thus, with a few rare exceptions such as teaching or serving as substitute judges, ${ }^{56}$ the profession of avocat is incompatible with any emploi a gages ${ }^{57}$ (employment for a salary) or louage de service 58 (hiring for services) because of the legal subordination inherent in such a relationship. However, while the texts are unanimous in the belief that the legal

50. Blanc, supra n. 32 at 55 .

51. See Law No. 71-1130, supra n. 7, art. 10, 70. The same prohibition applies to conseils juridiques.

52. See Brunois, Note, Cour de Cassation, 4 July 1972, Dalloz, 1973 at 251.

53. Lemaire, supra n. 22 at No. 471.

54. Law No. 71-1130, supra n. 7, art. 7; Decree No. 72-468, supra n. 6, art. 57-69.

55. Douai, 31 July $1843, S .43,2.460$, cited in Lemaire, supra n. 22 at No. 137.

56. The other exceptions are: associate judges of Tribunals for juvenile delinquents, and members of Social Security Commissions and Agricultural Credit Unions. See Decree No. 72-468, supra n. 7, art. 62.

57. Reglement Interieur du Barreau de Paris, art. 37. The term "gage" is generally used to designate a salary received by a domestic employee. But in the language of the bar, it simply means "salary," regardless of the type of employment. See Lemaire, supra n. 22 at No. 139.

58. Decree No. 72-468, supra n. 6, art. 62. 
profession is incompatible with legal subordination, therè is a divergence of opinion as to whether wage-earning by an avocat working for another necessarily implies legal subordination.

It is beyond dispute that an avocat's employment by a non-avocat will result in that avocat's disbarment. An avocat cannot work as a permanent collaborateur of an avoue, a notaire or a conseil juridique. Also, lawyers cannot be registered with the Bar if they work "in house" for private or public employers. Only permanent collaboration with another avocat is permissible.

The question remains however whether an avocat employed by another avocat can be a wage-earner. As previously discussed, ${ }^{59}$ the law organizing the legal profession is vague on this point. For example, the law uses the term "remuneration" rather than "salary" and "the person to whom he is bound" rather than "the employer."60 Traditionalists insist that the receipt of a salary from any source, even from another avocat, entails legal subordination and is thus incompatible with the profession. Although it has been argued that collaboration is an employment contract in view of the superior's liability for the collaborateur's activities, traditionalists maintain that this liability does not stem from a relationship of respondeat superior, but is simply a function of the non-delegability of the duty owed the client by the avocat. They characterize the contract between the avocat and his collaborateur as a contrat d'entreprise (work contract) in which the collaborateur retains his independence. ${ }^{61}$ Nevertheless, confess the proponents of this concept, to classify the contract of collaboration as a work contract sheds only the palest glimmer of light on the problem, considering the multitude of uncertainties which continually assail such a concept. ${ }^{62}$ They admit that "the legal nature of such a contract is not easy to grasp."63 Despite this difficulty, traditionalists are convinced that considering collaboration as salaried employment would be irresponsible in light of the law. ${ }^{64}$

Of course, there are certain external similarities between collaboration and employment. In both situations, the worker is assigned a particular place to work. The worker must conform to a time schedule set by his superior. There are no salaried employees below the collaborateur. Finally, the superior supplies the worker those things necessary for his work. These elements are adopted by the Cour de Cassation and other French courts to find an employeremployee relationship. ${ }^{65}$ Despite these similarities, the traditionalists remain firm in their insistence that collaboration is not an em-

59. See text accompanying $n$. 29-44 supra.

60. Law No. 71-1130, supra n. 7, art. 8, and Decree No. 72-468, supra n. 6, art. 74-76.

61. Jestaz, Revue Trimestrielle de droit civil 657 (1975).

62. Id.

63. Id.

64. See Procureur Géneral Picca's conclusions, Cour d'appel de Paris, 23 Feb. 1977, Dalloz 1977 at 193.

65. Camerlynck, 1 Traité du droit du travail No. 37-45. 
ployer-employee relationship, since such a view would render the relationship a "legal incompatibility." 66 They conclude that collaboration is a contrat innomme (contract without a name), a category by itself, unlike any contract known to French law. ${ }^{67}$

\section{The Functional Approach}

Other segments of the French legal community, especially "doctrine" (law professors and academicians), are critical of the traditionalist view. According to the Functionalists, it is unrealistic to deny the existence of an employment contract when the legal relationship between the avocat and the collaborateur exhibits all the characteristics of employment. ${ }^{68}$ They insist there is no textual basis for characterization of the contract of collaboration as unique. Such characterization would place the collaborateur in an uncertain status and deny him the social and financial advantages associated with the status of employee. ${ }^{69}$

The Functionalists argue that the avocat's independence is not compromised by the classification of a collaborateur as an employee. Merely calling the relationship one of employment does not sacrifice the avocat's independence, since the crucial question is that of legal subordination. If legal subordination exists in any relationship, be it partnership, association or whatever, incompatibility is present. Incompatibility occurs only if employment actually impairs the collaborateur's independence. For example, if a patron refused a collaborateur his own clients there would be an incompatibility. Also, if a collaborateur were threatened with dismissal for refusing to accept a case offensive to his conscience, there would be an incompatibility. A collaborateur would then be forced to choose between withdrawal from the relationship with his patron or disbarment. ${ }^{70}$

Functionalists cite the realities of other liberal professions to support their view. Architects are authorized to practice their profession as employees of other architects, as members of firms or as employees of municipal governments. ${ }^{71}$ Doctors remain members of the Medical Association and retain their professional freedom even though they are employed and paid by hospitals, are unable to set

66. Picca, supra n. 64 at 196.

67. Blanc, supra $\mathrm{n} .32$ at 58. 18676.

68. Chaput, Note, Tribunal d'instance de Paris, 5 April 1977, Semaine juridique

69. If collaborateurs are employees, the patron is required by law to pay their professional tax, social security contributions and other benefits such as vacation, right to notice and so on. Their relationship is governed by labor law which is geared to the protection of the worker. The law cannot be displaced by private agreement providing fewer benefits than those provided by law. See n. 4 supra.

70. Chaput, supra n. 68 at 18677.

71. Law No. 77-2, 3 Jan. 1977 (D. 1977.71), art. 14; cited in Jestaz, Note, Cour d'appel de Paris, 23 Feb. 1977, Dalloz, 1977, at 198. 
their own fees and are unable to choose their own patients..$^{72}$

The Functionalists argue that there is a distinction between "external" and "internal" independence and that the traditional incompatibility between the legal profession and the notion of "hiring for services" is based only on the fear that the avocat may be subjected to the will of an "outsider." An avocat cannot be a salarié vis-d-vis his client or any other "outsider." However if the employer is another avocat, the independence of the avocat collaborateur is assured since the law requires the strict absence of any legal subordination in such a relationship. Moreover, there is no express legal prohibition against the avocat collaborateur's characterization as a salarie. The debates on the Law of 31 December 1971 emphasize the legislature's deliberate silence on the matter. Thus the Functionalists conclude that even though an avocat collaborateur may be considered an employee of another avocat, there is no reason why this characterization should impair his independence. ${ }^{73}$

The Functionalists insist that the debate as to the status of the collaborateur must leave the realm of metaphysics and face contemporary realities. In recent years, legal practice has grown in both size and complexity. The practice of law in contemporary Europe requires large, sophisticated firms capable of dealing with the increasing diversification of the law. The efficiency required to render legal service dictates more structural organization within law firms. ${ }^{74}$ To the Functionalists, the subordination inherent in the employment status must be viewed as a positive organizational tool rather than a threat to the traditional concept of avocat independence. Currently, such "subordination" is no more than the "integration of a professional into the structure of a service or of an enterprise."75 To the Functionalists, "legal subordination" should be more appropriately termed "administrative subordination." "

Independence and employment do not exclude one another. For example, the Functionalists point to corporate executives who, although they are employees of the corporation, still retain the almost total independence necessary for making the decisions essential to the organization's existence. The Functionalist's approach is an attempt to reconcile the traditional ethical requirements of avocat independence with the organizational necessities of the new profession of avocat.

\section{The Avocat View}

The avocats themselves are divided on the question of charac-

72. Soc. 23 Jan. 1974, Bull. civ. V, No. 60 , p. $55 ; 5$ June 1975, id., V, No. 312 , p. 272; Dalloz 1975, I.R., at 168, cited in Note, supra n. 71.

73. Note, id.

74. Chirez, "La Qualité de Non Salarié de L'Avocat Collaborateur," 5 Droit Social, n. 65 at 145 (1978).

75. Camerlynck, supra n. 65 at No. 37-43, cited in Chirez, supra n. 74 at 146.

76. Chirez, id. 
terizing the relation between the collaborateur avocat and his patron. The division of opinion exists in both the membership of the National Association of Avocats as well as the membership of the National Association of Young Avocats. ${ }^{77}$

The split of opinion among senior avocats is largely pragmatic. Those who favor the classification of salarie for their collaborateurs do so largely on account of the organizational benefits inherent in such a relationship. The benefits include a more integrated office, greater collaborateur loyalty to the firm and total devotion of the collaborateur's time to the firm's affairs. Other avocats, especially the vast majority having smaller practices, find the organizational benefits minimal compared to the social and financial burdens resulting from the characterization of collaborateurs as employees. ${ }^{78}$

Although these social and financial burdens may be warranted as adequate compensation for the services of a full-fledged lawyer in permanent collaboration, they appear exorbitant for the minimal services rendered by the avocat stagiaire. Even those advocating the status of salarie for collaborateurs are aware of this problem. Many express the concern that few young lawyers will be able to find patrons willing to train them if they must be extended the benefits of a salarie as provided by law. A compromise has been sug. gested, providing that the collaboration of the avocat stagiaire be subject to the less demanding laws regulating apprentices of artisans. ${ }^{79}$

The young avocats in favor of the salarie status for collaborateurs are understandably attracted to the social and financial benefits of such a classification. Despite the obvious benefits, the majority of young avocats oppose the salarie classification. ${ }^{80} \mathrm{~A}$ recent congress of the Association Nationale des Avocats de France et de la Communaute explored the "Challenge of the Liberal Profession." One of the speakers, although admitting the material benefits of salarie to collaborateurs, urged his colleagues to "beware of the consequences of salariat." Salariat, he said, would deprive the collaborateur's rights to private clientele, the right to be free economically and intellectually. He urged the avocats to fight for a legal status incorporating all the fiscal and social benefits of salariat without being one. Hearty applause accentuated his remarks that avocats should resist the "employee mentality" and that sacrificing one's independence for immediate social and monetary benefits was to "besmirch the face of the (legal) profession."

77. See Chambonnaud, "La controverse collaboration-salariat" in Le Defi de la Profession Liberale, Association nationale des Avocats, 203 (1974). The National Association of Avocats and the National Association of Young Avocats are private organizations:

78. See $n .69$ supra.

79. Chaput, see n. 68 supra at 18677 , and Jestaz, n. 71 supra at 199.

80. Chambonnaud, supra n. 77 at 196.

81. Id. at $210-15$. 


\section{The Debate Before the Courts}

Although the French courts retain the ultimate power of review over the administrative proceedings of the French Bar, ${ }^{82}$ until Mme $\mathrm{X}$ brought her case before the Tribunal de la Seine, the Courts had not entered the debate over the status of the collaborateur. This was due largely to the fact that disputes between collaborateurs and their patrons were rarely pursued beyond a hearing before the Batonnier, since avocats as a profession are generally reluctant to air their "dirty linen" in public. Mme X, however, was not satisfied with the Batonnier's recommendations and took her case to the Tribunal de la Seine. Applying the procedures of labor law, the Tribunal ordered the parties to appear for a conciliation. The defendant Association of Avocats failed to answer the summons and the Tribunal declared the conciliation unsuccessful. The Tribunal then ordered the parties to appear on 5 July 1976. During the personal appearance, the defendant refused to respond, alleging that the Batonnier of the Paris Bar had ordered it not to argue the merits of the case. The defendant argued that sitting as a labor court, the Tribunal lacked jurisdiction since the law dictated an inviolable incompatibility between the legal profession and a "hiring for services" contract.

On 9 July 1976, the Tribunal entered a judgment ordering an investigation into the facts surrounding Mme X's collaboration with the defendant. The Tribunal did not rule on the merits of the defendant's jurisdictional argument. The defendant appealed and was joined by the Batonnier representing the Paris Conseil de l'Ordre ${ }^{83}$

Before the Paris Court of Appeals the appellants argued that by ordering an investigation into the facts of Mme X's case, the Tribunal de la Seine had implicitly conceded the possibility of the existence of a labor contract and that such a concession prejudiced the appellants' case. Further, the appellants reiterated the argument that the entire matter of Mme X's collaboration was outside the jurisdiction of the labor courts due to the incompatibility between the status of avocat and the status of salarie.

In rejecting the appellants' arguments, the Paris Court of Appeals declared that in ordering an investigation into the nature of the legal relationship between the plaintiff and her employer, the lower court had not prejudiced the case. The Court further declared that the determination of the jurisdiction of the lower court is predicated upon the nature of the contract between the parties; absent a written contract required by law, the lower court was justified in

82. Law No. 71-1130, supra n. 7, art. 24; Decree No. 72-468, supra n. 6, arts. 99-103, 119-126. The avocat and/or the prosecutor appeal the decisions of the Conseil de l'Ordre before the Cours d'appel.

83. The Conseil de l'Ordre has the authority to enter any dispute affecting the practice of the profession, particularly where "the rights or prerogatives given to avocats by laws, decrees or regulations have been ignored or questioned." See Cremieu, Note Dalloz, 1955.417; and Law No. 71-1130, supra n. 7, art. 21. 
looking to the facts of the case to determine whether there was an employer-employee relationship cognizable by labor law. The Court of Appeals thus found the lower court had not improperly attempted to determine the jurisdictional question. The appeal was dismissed. ${ }^{84}$

Following the decision, the investigation ordered by the Tribunal de la Seine continued. After the completion of its investigation, the Tribunal handed down its decision on 8 April 1977.85 The court began by noting that there was no written contract between Mme X and the firm of Avocats as required by law. In the absence of a written contract, the Tribunal was required to look into Mme X's particular employment situation to determine the nature of the relationship between the parties. The Tribunal found the following facts crucial: (1) Mme X was employed full-time according to a schedule determined by her patron. (2) She was not the master of her arguments. Those cases she argued in court were prepared by other avocats of the firm. With few exceptions Mme X could not meet the clients. (3) Mme X engaged in no intellectual work, handling only material, trivial chores "similar to those handled by the clerical staff." She took oral or written orders from her superiors. (4) Mme X's compensation was fixed and unrelated to the actual work done. The Tribunal remarked however that salariat and avocat independence are not incompatible, as evidenced by the practices of the medical profession. (5) Mme $\mathrm{X}$ worked in a salle commune (common room). Although it was not forbidden for Mme $\mathrm{X}$ to receive her private clients, she had to receive her clients in the salle commune "in the midst of voices, the sounds of telephones, tape recorders, dictaphones and general hustle and bustle. . . .86 Only rarely, if the client was "important," could Mme X use a partner's or permanent collaborateur's office. The Tribunal considered this lack of privacy for Mme X and her clients an impairment of her right to client confidentiality regardless of the client's financial importance.

The Tribunal found that Mme X

was integrated into the structure of service in which her work was effectively directed and controlled by oral and written orders for which she was responsible; thus there existed between her and the association of avocats employing her a bond of subordination rendering her dependent upon her patron; [and] that this dependence was a serious impairment of the freedom that an avocat collaborateur should enjoy. ${ }^{87}$

The Tribunal also found that fixed compensation constituted a salary, indicative of subordination. The Tribunal believed that al-

84. Cour d'appel de Paris, 23 Feb. 1977, Dalloz 1977, at 193.

85. Tribunal d'instance de Paris, 8 April 1977, Dalloz 1977. I. 589.

86. Id. at 590 .

87. Id. 
though the salariat is compatible with independence, Mme X's situation went beyond a mere salariat to legal subordination. The Tribunal found in Mme X's situation an association of six patrons with twelve collaborateurs which destroyed the equality that should exist among avocats. The Tribunal concluded that Mme X's association "was in fact an enterprise including employers and employees; [resulting in the modification] of the nature of the contract between Mme X and her patrons, requiring direction and control which are the characteristics of subordination and dependence."88

Based on its findings as to the nature of Mme X's employment, the Tribunal de La Seine found it had jurisdiction to act as a labor court and rule on the merits of her complaint alleging improper termination of her employment. The Tribunal dismissed the intervention of the Conseil de l'Ordre and, under the applicable provisions of labor law, ordered the defendants to pay Mme X F.2500 as one month's wages for notice, F.250 for accrued vacation time and F.10,000 as punitive damages for abusive termination of her employment contract.

Regrettably, the Tribunal de la Seine's decision provides at best a confused answer to the question of whether salariat, by its very nature, engenders subordination incompatible with avocat independence. The Tribunal began by intimating that salariat and avocat independence were compatible. The Tribunal went on however to state that the receipt of fixed compensation was indicative of subordination. Although the Tribunal entertained the concept of "administrative subordination" in stating that integration into a structure necessarily implied direction and control, it left unanswered the question whether "administrative subordination" runs counter to avocat independence. Although the Tribunal apparently answered this question in the affirmative by noting that "an association of six patrons facing twelve collaborateurs would render non-existent the equality which should, in theory, reign (among the avocats) of this firm [,]"89 the questions remain whether a collaborateur should be disbarred for agreeing to be integrated into such a structure and whether sanctions should be imposed upon the patron for providing such a structure.

\section{The Legislature's INVOLVEMENT}

The defendants and the Batonnier of the Paris Bar appealed the judgment of the Tribunal de la Seine to the Court of Appeals of Paris. While the appeal was pending, an attempt was made in the French Parliament to influence the outcome of the appeal. This attempt took the form of a rider attached to a projet de loi (bill) introduced by the government to modify the requirements set in Law No. 71-1130 for obtaining the degree of a licence en droit and for admis-

88. Id.

89. Id. 
sion to the legal profession. ${ }^{90}$ The government had tried unsuccessfully to effect the reform by decret (executive order). ${ }^{91}$ A new school year was almost at hand and the government was eager to have the legislature validate its proposal. ${ }^{92}$ Since the projet de loi had a very limited objective, ${ }^{93}$ it was curious that a member of the Assemblee Nationale, a former Batonnier of the Bar of Chartres, would seize the occasion to introduce an additional article to the government's projet de loi which was totally beyond the bill's objective. The new provision, art. 3 , provided that "the avocat who practices his profession as an avocat collaborateur, as a member of a legal corporation or partnership, cannot be an employee. The present disposition, which is interpretive, has the effect of ordre public."94 The amendment was so remote from the objective of the original projet de loi that the Commission des Lois of the National Assembly rejected it outright. In explaining the rejection of the amendment however, the President of the Commission made the mistake of commenting upon its merits. In expressing his opinion that it was wrong to deny the collaborateur the status of employee since the collaborateur often lives in difficult conditions and needs at least a minimum "social cover,"95 the President of the Commission unleashed a renewal of the perennial debate.

The Minister of Justice endorsed the Commission's rejection of the amendment and urged the National Assembly to do the same. The Minister pointed out that since Law No. 71-1130, organizing the new profession of avocat, contemplated the ultimate consolidation of the professions of conseil juridique and avocat, and since the conseil juridique can retain other conseils juridiques as employees, to refuse avocats the status of employee would be tantamount to a termination of the ongoing merger negotiation between the two professions. A member of the National Assembly questioned the Minister as to whether he was advocating a union of conseil juridique and avocat which would result in the demise of avocat independence. ${ }^{96}$

The author of the amendment confronted his colleagues with this logic: either the legal profession is "liberal" and "independent" with the result that no lawyer can practice his profession as an employee, or collaborateurs are employees and are subject to legal subordination. The first alternative is the "obvious" choice and emphasizes the need for the amendment. The second alternative is clearly against the law. ${ }^{97}$ Ultimately, since the government did not

90. See n. 18 supra.

91. The decret was challenged on the ground that, being issued by the Executive, it cannot modify a law.

92. The proposed new Licence en droit requires three years of study instead of four. Admission to the legal profession requires an additional year and a maitrise (master degree).

93. J.O., Assemblee National, 23 June 1977 at 4105.

94. Id. at 4107.

95. Id. at 4104 .

96. Id. at 4107-08.

97. Id. at 4109 . 
wish to jeopardize the chances of quick approval of the bill by risking what would have been a protracted debate on avocat independence, the amendment was quickly approved by the National Assembly.

When the projet de loi went to the Senat for consideration, the government made a final attempt to have the amendment dropped from the bill, arguing that the status of the collaborateur "is a great problem which would require a great debate, ... . which does not find its place in the framework of a projet de loi with a very limited and specific purpose."98 The Senat Commission des Lois, however, did not agree with the government. The Commission's rapporteur appealed to the Senat's respect for the "sacrosanct power of the Parliament," which had solemnly expounded in Law No. 71-1130 that the legal profession is "liberal" and "independent." The rapporteur again reminded the members of the Senat that avocat independence and salariat were incompatible. ${ }^{99}$

Evidently few members of the Senat were inclined to challenge the "sacrosanct power" of Parliament. The amendment was quickly approved by the Senat on 29 June 1977 and promulgated by the government on 30 June 1977.100

There is an obvious explanation for the haste with which the amendment made its way through the legislature. The Conseil de l'Ordre of the Paris Bar sought such legislation to guide the hand of the Paris Court of Appeals in deciding Mme X's case. It is not insignificant that $\mathrm{Mr}$. Gerbert, the amendment's author, is himself a former Batonnier. The driving force behind the amendment is most evident in the comments of a Senat member who noted that "the courts need to be enlightened," and that the purpose of the amendment was to "make it impossible for the courts to misinterpret the law."101

Art. 3 of the Law of 30 June 1977 on collaboration concludes with the provision that it is "interpretive" and has the character of "ordre public" (public policy). Because of these two provisions, art. 3's scope is broad.

A law is "interpretive" when "it is limited to identifying, without changing, an existing right which an imperfect definition would make susceptible to controversy."102 Since it theoretically adds nothing to an already existing law, interpretive laws are retroactive. ${ }^{103}$ Thus the relationship between avocat and collaborateur as characterized by art. 3 applied retroactively to all such relationships

98. J.O., Senat, 29 June 1977 at 1920.

99. Id. at 1921-22.

100. Law No. 77-685, 30 June 1977, modifying art. 7,11,12,17 and 54 of Law No. 71-1130 of 31 Dec. 1971 on Reforms of Certain Legal Professions. J.O., 1 July 1977 at 3433.

101. J.O., supra n. 98 at 1922.

102. Soc., 19 June 1963, Gaz. Pal. 1963 I. 278.

103. Under art. 2 of the French Civil Code, laws are non-retroactive. However, this principle applies only to judges and not to legislators. The non-retroactivity principle can be set aside by (1) a law expressly declared retroactive, (2) a law validating prior 
dating back to the time of the promulgation of the 1971 law on the profession of avocat. As a result, the new law governs and characterizes the relationship between Mme $\mathrm{X}$ and her patron. Under art. 3 , Mme X could not have been a salaried employee of her patron. This finding is strengthened by art. 3 , which has the authority of ordre public. Ordre public governs the freedom of contract and private parties. ${ }^{104}$ French law provides that generally parties are free to contract as they please. Such agreements "have the force of law for those who have made them." 105 However, a contract made for an illegal purpose is unenforceable. A purpose is illegal when it is prohibited by law or when it is contrary to ordre public or bonnes moeurs (good morals). Art. 6 of the French Civil Code provides that "laws relating to public order or good morals cannot be derogated by private agreement." Laws such as art. 6 are lois imperatives (imperative laws) which take priority over any parties' agreements to the contrary. A contract in violation of a loi imperative is deemed to have an illegal purpose and is thus a nullity. ${ }^{106}$

Lois imperatives are unambiguous expressions of the legislature's view of ordre public "indispensable to the maintenance of the social order."107 Lois imperatives are considered the means by which the nation is protected from the threat of unbridled private contract. ${ }^{108}$ That the authors of art. 3 drafted the prohibition of salariat between avocats as an ordre public provision indicated their intention to leave the Court of Appeals no choice but to rule against Mme X. One commentator observed that "the evil of the salariat classification for collaboration [must have been deemed by the legislators] so substantial that they decided to use such radical remedies."109

\section{The Second Decision}

The classification of art. 3 as interpretive made its applicability to Mme X's case automatic.110 Mme X's patron and the Batonnier of the Paris Bar were thus supplied with a formidable weapon. They argued that since the prohibition against salariat was ordre public, Mme X could not claim she was an employee and ask to receive the benefits conferred by such a status. Additionally, the la-

acts considered null and void or (3) a law expressly qualified as interpretive. See Carbonnier, Droit civil 131-35 (1974); Marty-Raynaud, Droit civil 184-97 (1972).

104. Ordre public is also used by French judges to ignore a foreign law applicable under French conflict of laws rules. In this respect, ordre public is comparable to "public policy" in American law, although its scope is broader. See Batiffol \& Lagarde, Droit International Privé 444-70 (1974).

105. French Civil Code, art. 1134.

106. Id., arts. 1131, 1133.

107. Marty-Raynaud, supra n. 103 at 175.

108. Carbonnier, supra n. 103 at 108.

109. Chirez, supra n. 74 at 149.

110. See n. 103 supra. 
bor court could not have jurisdiction over the present dispute between avocats.

In its decision of 7 November 1977, the Paris Court of Appeals refused to defer to the legislature's will.111 The court first addressed the legal profession's incompatibility with the "hiring for services" contract as delineated by the Decree of 9 June 1972.112 The court found this incompatibility to be only an "external incompatibility." As such, the law prohibited only employment relationships between avocats and non-lawyers, since such relationships could impair the "liberal" and "independent" character of the avocat. When the relationship is between avocats exclusively however, the court held that courts must look to the true nature of the specific relationship involved. Absent a written contract, as in Mme X's case, the courts must look to the circumstances surrounding the relationship to determine its true nature. After examining the circumstances, the court concluded that "all the usual characteristics of legal subordination were present."113 Significantly, the court noted that an employment contract is not per se incompatible with the "independence required in an avocat's rendering assistance to and representing his clients."114

The court's finding was rather curious. First the court took into account the circumstances behind the bill's quick movement through the legislature. The court emphasized particularly the fact that the bill was introduced while the court was still deliberating upon Mme X's case, despite the opposition of both the Commission des Lois and the Minister of Justice. Second, the court ruled that the law applied only to: (1) members of legal corporations, (2) members of partnerships or (3) collaborateurs. Outside these categories, said the court, the status of employee is not ruled out. In the present case, absent a written agreement, such a status was found to exist through the conditions surrounding Mme X's employment: Mme X was assigned fragmentary and trivial work, she was confined to a common office, had no real independence, was deprived of any significant initiative, and could only take explicit orders. In short, the court found Mme X's status that of veritable subjection. The court further declared that since Mme X's employers had failed to provide her with a written contract as provided by law, they had failed to abide by the law and hence infringed upon her independence. ${ }^{115}$ As a result, the court affirmed the lower court's award of both compensatory and punitive damages. ${ }^{116}$

111. Cour d'appel de Paris, 7 November 1977, Dalloz, 1977 at 652.

112. See $n$. 58 supra.

113. Cour d'appel de Paris, supra n. 111 at 655.

114. Id.

115. Id. at 656.

116. At the time of writing, the case of Mme $\mathrm{X}$ was being appealed to the Cour de Cassation. 


\section{The Unresolved Issues}

Although the commentators did not object to Mme X's vindication in the Court of Appeals, they criticized the court's handling of the concepts at issue in the case. ${ }^{117}$ For the court to carve out of art. 3 an exception for collaboration between avocats, to declare that no collaboration existed between Mme X and the other avocats, is unjustified by any possible meaning attributable to the law. The commentators criticize the court for gutting the law of its substance 118 by "sullenly" refusing to apply the law as written. They wrote that the court should have stated in which circumstances the inevitable dominance of the patron results in the legal subordination of the collaborateur, rendering the relationship between them both illegal and unethical. Rather than draw the line between legally and ethically approved collaboration and unallowable legal subordination, the court merely blurred further an already undefined distinction. ${ }^{119}$

As a result, the "mini-revolution" begun by Mme X's case did little to clarify the legal status of the collaborateur. Although the controversy did result in the enactment of art. 3 and its provision that, as a matter of public policy, the collaborateur cannot be employed in "legal servitude," the exact nature of "legal servitude" is hopelessly unclear. Thus the conflict between avocat independence and the organizational realities of modern collaboration in French law practices remains unresolved.

\section{The AMERICAN Model}

In the United States no one disputes the view that associates are employees. The term "associates," when used by the American Bar Association, designates "attorneys who are employed by another attorney or law firm and do not share responsibility or liability for the acts of the firm."120 Additionally, the National Labor Relations Board has interpreted the National Labor Relations Act to treat associates as employees. ${ }^{\mathbf{1 2 1}}$

In America as in France, however, the model of the lawyer as an independent professional is still nurtured. The American Bar Association's Code of Professional Responsibility speaks of the "independent professional judgment" of the lawyer on behalf of the client.122 Geoffrey C. Hazard, Jr. considers "analysis of the legal and practical dimensions of the clients' position, evaluation of the risks

117. See Jestaz, Dalloz, 1977 at 652 and Chirez, supra n. 74 at 150.

118. Jestaz, id.

119. Id.

120. A.B.A. Commission on Professional Ethics, Opinions, No. 310 (1967).

121. However, few associates seem anxious to unionize. They are afraid that unionization may jeopardize their chance for promotion in the firm. Pressures of conformity are such that even among associates there is a perception that those who seek unionization are "either mediocrities in need of such group support, or masochists." See Sloane \& Witney, Labor Relations 14 (1977) cited in Note, "Unionization of Law Firms," 46 Fordham L.Rev. 1008 at 1029 (1978).

122. A.B.A. Canons of Professional Ethics, No. 5. 
and potential gains involved in pursuing alternative courses of action ... . and recommendation of what the lawyer believes to be the optimal course of action for the client" 123 the hallmarks of the legal profession. The French notion of avocat independence is echoed in William Kornhauser's view of the American professional's "extensive autonomy in exercising a special competence." 124

Despite the theoretical similarity between French and American notions of professionalism, autonomy is perhaps the least visible attribute of associates in American law firms. Unlike their French counterparts, associates are not allowed to have their own exclusive clientele. ${ }^{125}$ If associates do have personal clients, they may be forbidden from receiving them at the firm's offices. If individual associates' clients are brought to the firm, they may be considered the firm's clients rather than the associate's. Generally, inexperienced associates are assigned particular aspects of a client's work. Often the associate is unaware of the client and equally uninformed about the broader aspects of the particular problem upon which he is working.

Although the Code of Professional Responsibility provides that "a lawyer should represent a client zealously within the bounds of the law," 126 many associates in reality work for their supervising partner rather than the client. Even where he has contact with the client, the associate can rarely act according to his own beliefs as to the client's best interests. When associates of a large Wall Street firm were asked whom they try to please, their supervising partner or the client, the common answer was that primary responsibility was to the partner rather than the client. ${ }^{127}$ One associate confessed: "I have had to do things I thought were not right for the client, but the client is not the individual lawyer's but the firm's client. When the firm fixes policy, that has to be my own policy."128 Another associate felt that associates inevitably become "yes-men."129

It has been suggested that associates are traditionally expected to debate questions of law with their superiors. ${ }^{130}$ A partner in a large firm expressed the opinion that if there were cause for a debate upon a legal matter, he "would feel horrified if [the associate] did not raise hell."131 But associates are well advised to take such

123. Hazard, Ethics in the Practice of Law 77 (1978).

124. Kornhauser, Scientists in Industry: Conflicts and Accomodation 11 (1962) cited in Smigel, The Wall Street Lawyer 265 (1973).

125. A Cleveland firm, perhaps the last bastion of associate autonomy, allowing associates to operate their own private practice while maintaining their affiliation with the firm, finally had to give up this system because "it just became too difficult to manage." The National Law Journal, 28 January 1980.

126. A.B.A. Canons of Professional Ethics, No. 5.

127. Smigel, supra n. 123 at 299.

128. Id. at 298 .

129. Id.

130. Smigel (n. 123 supra) noted that this is the main difference between law firms and other bureaucratic organizations.

131. Smigel, id. at 322. 
statements with a grain of salt. The associate must know when to desist in any debate with superiors. Although his failure to argue a point of law may detrimentally affect an associate's opportunity for promotion, not to know when to stop is fatal. An associate does not often take the disagreement to the firm's client. Since, as a practical matter, associates work for their firm and not the client, going past a superior to the client might be tantamount to professional suicide. French law protects the collaborateur's right to turn down assignments he considers against his conscience, but in American law an associate's right to refuse an assignment is "unusual."132 If the Code of Professional Responsibility states "comprehensively the rules by which lawyers should perform their calling,"133 the code apparently does not apply to associates. Since the organizational realities of American law firms dictate that associates obey orders, associates must forego autonomy. As the firm grows larger, the greater is the need for integration and the broader the gap between ethical dictates and organizational realities.

The American Bar allows for the sacrifice of associate autonomy by distinguishing between "internal" as opposed to "external" controls of associates. Essentially, although control of lawyers by sources external to the firm is impermissible, control from within the organization is not merely "proper" but "salutary."134 This distinction between internal and external controls however is perhaps little more than an ex post facto rationalization of organizational realities, since both controls prevent the lawyer from "performing his calling" and exercising his "independent professional judgment."

Curiously, although individual lawyers and associates feel the strain of the dilemma, ${ }^{135}$ the American legal community has failed to address itself to the conflict between the ethical dictates and the organizational realities of the profession. This indifference is perhaps part of an ideological shift in American society. The autonomy and non-conformity inherent in the Protestant Ethic may have been displaced by a growing belief in the value of teamwork. Teams must be organized to be effective. In a law firm, organization means taking orders and respecting organizational rules.

\section{CONCLUSION}

The American organizational model has had an impact on French society. ${ }^{136}$ With the growth and prosperity of France in the "hour of Europe," the French legal community is acutely aware of the need for reconsideration of the value of organizations. But

132. Id. at 331.

133. Hazard, supra 122 at 19.

134. Commission on Professional Ethics, Opinions, No. 334 (1967).

135. See Smigel, supra n. 123 at 205-340.

136. See, for example, Servan-Schreiber, Le Defi Americain (The American Challenge, translated from French by Ronald Steel). This French best-seller extols the virtues of the American organizational model. 
many avocats are unwilling to renounce professional independence and accept the American model. The tension between the past and the present, the struggle between professional independence and organizational dictates, and the search for a way to reconcile these contradictory forces have all contributed to the as yet unresolved "mini-revolution" concerning the status of the collaborateur. 